DOI: doi.org/10.21009/IJLECR.052.16

Received: 5 June 2019

Revised: 10 June 2019

Accepted: 14 August 2019

Published: 31 December 2019

\title{
MYSTICAL COMMODIFICATION IN JARAN GOYANG SONG: AN APPROACH TO LITERARY SOCIOLOGY
}

\author{
Philosa Kasyutiantara Denpabhara, ${ }^{1, a)}$ \\ Magister Kajian Sastra dan Budaya Universitas Airlangga Surabaya ${ }^{1)}$ \\ pk.philkill@gmail.com ${ }^{\text {a) }}$
}

\begin{abstract}
Indonesia and the practice of shamanism are two components that cannot be separated. It has been rooting since the old-time ancestors of animism-dynamism, and has already become one of the cultures of its people. However, one interesting fact is that the topic of shamanism is not only discussed through daily practice, but also through entertainment industry. One of the Indonesian songs which has become well known in April 2017 with the theme of shamanism is Jaran Goyang which was popularized by Nella Kharisma and is currently listed on the top 10 Indonesian's highest viewers of all time. The song in that particular year created the sprung of other songs with similar themes. Shamanism, which related a lot with black magic and is considered as grave sin in many religions (especially Islam), now become commodified in the entertainment industry to seek for exchange rate. Therefore, the phenomenon rises two questions that the writer would like to answer in this research: (1) How is mystical phenomenon be marketed; and (2) What ideology helps the commodification of mystical phenomenon.
\end{abstract}

Keywords: Commodification, Jaran Goyang, Literary Sociology, Media, Shamanism

Before money was invented, any transactions were made based on mutual agreement. However, it all changes when money started to dominate daily economical transactions that it even became a measurement for one's social stratification. From all of those changes, there is one particular interesting phenomenon in Indonesia that was triggered by the use of money: mystical phenomenon with materialistic motive. The strong motivation to own success instantly combined with a strong believe towards mystical entity have led many people to this dark path. Inevitably, shamanism which offers many alluring rewards with the help of the spirits becomes an enormous business. They have many purposes aside from getting financial wealth such as to gain power, fame, immunity, beauty, or greater odd in romance.

However, it does not mean that shamanism have the spotlight to be called as a friendly method in gaining personal wealth. It is still considered as a daunting business which is also incredibly taboo. The discourse is also supported with many religious texts in Islam which forbid the practice of shamanism since it means to betray God. In Arabic, this shamanism is translated as kahana which means solving problem through the help of supernatural entities (Fariadi 2013). Cliffort Geertz (1963) states that the practice of shamanism is identical with the locals, traditional believes, and animism. Nevertheless, one interesting phenomenon rises when this taboo practice was being openly discussed by the public when it enters entertainment field: popular song.

One of the Indonesian songs which has become well known in April 2017 with the theme of 
shamanism is Jaran Goyang which was popularized by Nella Kharisma. The song was uploaded to the Youtube social account by DD Star Record and it managed to get 110 million viewers in just over 7 months. Until now, the viewers has reached 236 million and thus made it to be included in the top ranks of Indonesian songs in term of highest number of viewers (Kworb.net). This song basically tells about a woman who broke up with her partner and then uses the help of a shaman to use a spell called Jaran Goyang and Semar Mesem to make her partner return to her embrace.

Jaran Goyang is not the first song that was famous with the theme of shamanism. The song Mbah Dukun which was popularized by Alam in 2007 also tells a similar theme. It tells a story about someone who asks the help of a shaman to make a woman falls in love with him. However, the interesting point which underlies the phenomenon of Nella Kharisma's Jaran Goyang is the number of shamanic-themed songs which appear in close proximity, such as Jurus Perindu (August 2017), Dukun Cinta (September 2017), and Semar Mesem (October 2017). This is the reason for the writer to examine the phenomenon of the increasing use of mystical narratives as a form of commodification of the Indonesian entertainment industry.

\section{METHOD}

Sociology of literary works puts its focus and attention to the content of literary works, goals, and other implicit things in the literary work itself and it is always related to social problems (Wellek and Warren, 1994). In the relationship between literary works and reality, Teeuw (1988: 228) explains that not only literary works are born from the exemplary of reality, but they are simultaneously act as real models of reality. It is not only literature that mimics reality, but there is often a norm of beauty recognized by certain people revealed in works of art, which is then used as a benchmark for reality.

Therefore, according to Junus (1986: 3-5), the sociology of literary works that see literary works as socio-cultural documents is characterized by several things. First, the elements (contents / stories) in the work are taken regardless of their relationship with other elements. The element is directly connected with a sociocultural element because the work only moves that element into itself. Second, this approach can take an image of something, for example about women, men, foreigners, traditions, the modern world, etc., in a literary work or in some work that might be seen in a developmental perspective. Third, this approach can take motifs or themes contained in literary works in relation to the reality outside literary works. This approach has a tendency to see a direct (one-to-one-respondent) relationship between elements of literary works and elements in the society depicted in that work (Swingewood, via Junus, 1986: 7). In this article, the writer uses the third type of approach.

Therefore, data collection and analysis move from elements in literary works to elements in society, and interprets the relationship between the two. This study uses the lyrics of the song Jaran Goyang which triggers the creation of songs with other shamanistic themes all of which are used to pursue someone's love by using supernatural means. This writer uses a qualitative descriptive approach, using quantitative data. The writer utilizes the sociological perspective of literary works and uses the theory of commodification of media content belonging to Vincent Mosco. The focus of the writer is to answer these questions: (1) How is mystical phenomenon be marketed; and (2) What ideology helps the commodification of mystical phenomenon.

\section{Commodification}

In his book, Vincent Mosco (2009) states that commodification is a process that describes how capitalism obtains capital or value through value transformation so that it has an exchange or commercial value. In this process of commodification, something is produced not primarily on the basis of use value, but rather on exchange value. That is, something in production does not merely 
have a use for the audience, but rather because something can be exchanged in the market. The use value of an object is its use, which is related to the fulfillment of certain goods. Meanwhile, the exchange rate is related to the value or price of the product / goods in the market. The object of this exchange rate is called the commodity form of an object (Lubis 2014).

Furthermore, Mosco explained that there are two forms of commodities in communication, namely the commodification of media content and the commodification of audiences. Both types of commodities are contained in intrinsic commodification, where the exchange rate that the media seeks to obtain comes solely from the interaction between content and audience. It's just that, in this article the writer will only use the commodification of media content, which is most appropriate as the writer's mean to analysis. The researcher's focus is on dissecting how spiritual entities are used as objects of conversation on Indonesia's entertainment stage.

\section{Commodification of Media Content}

\section{RESULTS AND DISCUSSION}

In the terminology of sociology, there is one interesting concept which is trust. Trust means believing in some quality or attribute of something or someone, or the truth of a statement. Torsvik (in Damsar, 2011: 185) states that trust is a certain behavioral tendency that can reduce the risk of conflict. Another opinion is expressed by Lawang (in Damsar, 2011: 186) whom states that trust is a relationship between two or more parties that contain expectations that the relationship of one party or both parties through social interaction is beneficial. From the several definitions of trust that have been described above, it can be concluded that trust is an act of acceptance of an individual or a group. In this case, people who have high level of trust would assume positively on everything that they have believe on. If it is related to the research that writer do, then the trust takes place between the community towards the shaman. The community trusts the shaman in their strong capability to solve various problems in life. For example, the problem of love, financial, or career to simply possess high status or other motives in a pretty much instant way.

In facing various problems, there are two options that humans could choose: some choose rational solutions, while some believes that irrational solutions are better. A rational way of thinking stresses on logical and empirical ways of thinking. While it is reassuring to have some valid facts to support one decision making, it does not necessarily mean that there are not many people that seek irrational way of thinking by believing any mystical things. One of them is looking for a way out of the problem through shamanism. Usually, religion and faith towards religion is used as an ultimate problem solver as God is the Almighty that could solve any problems that any human possesses. However, many are on the contrary side to religion since most of the time they could not vividly see God as the object that could work as a fast nor effective problem solver.

Some religious practitioners consider Jaran Goyang as crossing the line since the lyrics are in the contrary with the teachings of the majority religion in Indonesia, namely Islam, for not asking for help from other than God the Almighty. This is called as shirk and is considered as a grave sin since it believes that humans have great power by cooperating with Jinns or spiritual entities. Jaran Goyang tells the story of a broken-hearted person since she (the writer assumes that the main character is a girl since it was sang by a girl singer) was dumped by his lover. Since the girl was still in love with her lover, she was willing to do anything including asking the help of a shaman take back his lover. The unique thing about the lyrics of Jaran Goyang is the explicit invitation to go to the shaman, as in the following lyrics:

Wes cukup stop mandekko disek sek sek

[It is enough, just stop already]

Jangan bicara jangan berisek sek sek

[Do not talk just yet, do not be noisy] 
Gek ayo ndang mangkat ndukun, rasah kakean ngelamun

[let's go to a shaman right away, do not need to daydream a lot]

Ndukun, ndukun, ndukun ayo ndukun

[shaman, shaman, let's go to a shaman]

This is different from the song Mbah Dukun, which was popularized by Alam in 2003. The song still talks about the great power of God which lies above all else and urges not to depend entirely on the shaman. That depiction can be seen in the following lyrics:

Dan Tak Lupa doaku Paling Utama

[I do not forget that my prayer is the most essential part]

Kepada Tuhan Yang Maha Kuasa

[a prayer to God the Almighty]

Semoga Cinta Kami Abadi Selamanya... Yeess!

[I pray that our love ought to last in eternity, yes!]

(Mbah Dukun, Jangan Takabur Yach! Tuhan Yang Menentukan Mah...!)

[dear Shaman, do not be arrogant! God is the one who determines everything!]

The difference in the content of the song Mbah Dukun with Jaran Goyang which includes an explicit invitation to go to the shaman reap a lot of controversy, especially among people who rejects the notion of shamanism since it is considered as offensive towards God in Islamic religion. Since then, there were a lot of counter narrations, from scientific articles to rival song covers, that basically say to worship diligently to get God's help. Even so, it is indisputable that the incantations of Jaran Goyang and Semar Mesem are considered to be very effective in making a person to fall in love to death for the person who requests it. The reality that is captured in the song's lyrics reflects how the actual spell of Jaran Goyang works, as in the following lyrics:

Kalau tidak berhasil, pakai jurus yang kedua

[if it does not work, use the second spell]

Semar mesem namanya, jaran goyang jodohnya

[it is called Semar Mesem, it goes really well with Jaran Goyang]

Cen rodok ndagel syarate, penting di lakoni wae

[the requirements are a bit absurd, just do it anyway)

Ndang di cubo, mesthi kasil terbukti kasiate, gejrot!

[go and try it right away, it must work very well, gejrot!]

As stated in the lyrics of the song above, the person affected by the spell of Jaran Goyang will experience a number of things that are considered odd. Some of the signs are that they will suddenly feel a very deep longing for someone, every night they will feel restless and want to always be with that person in their shadow, they will have trouble sleeping, feel depressed, and grimace like a horse in the middle of mating season. This is why this spell is called as Jaran Goyang, which translates as a dancing horse (Aulawi 2017). Before mastering this spell, one must perform the requirements including white fasting for seven days. White fasting means that one is allowed eating only three scoops of rice on each suhoor and breaking the fast. During fasting, a person is required to protect their five senses from the exposure of dirty things. All of these requirements which are presented on the lyrics of Jaran Goyang might be considered as the "absurd things".

Mystical phenomena in the form of spell activities performed by shamans becomes the trading object. In the commodification of media content, the message or product content is the form of commodification that collects information. Those data are then being processed in such a way by 
the media to get an "exchange value". The contents of the media, particularly the mystical issues in the lyrics of Jaran Goyang, became an issue that was successfully commodified in Indonesian society. This can be seen from the overwhelming response of the community, both negative and positive. In fact, the high amount of views and interest in Jaran Goyang also made many recording houses to make more songs with similar themes. This is also because most Indonesian people still believe in mystical powers (which later this part of sociological background will be discussed on the next sub-topic).

This is in accordance with the commodification of Moscos which says that the commodification of the content is happened when the producer produces text(s) by adjusting to the tastes of the market. When seeing that the community's response to Jaran Goyang was enthusiastic, it was not surprising that many other recording houses adopted similar themes. This activity is triggered by the possibility of the high exchange value that can be achieved by media owners related to the popularity of Jaran Goyang. In the entertainment stage, supernatural and mystical activities (which are actually pretty daunting in real life) had turned into jokes and being openly discussed without any limitation created by taboos.

\section{Mysticism:}

In this section, the writer tries to talk about the ideological background of mysticism that led to the success of mystical commodification in the Indonesian entertainment industry. This is due to many of the audience are Javanese (it can be seen from the lyrics of Jaran Goyang, which mostly uses Javanese) are still adhere to mysticism (have believe in the power of spirits). The striking characteristic of the structure of Indonesian society, especially in Java during the Hindu-Buddhist period, is based on customary law rules and its religious system. They are called as animismdynamism which is the core of culture of many Javanese people. Customary law acted as a norm that binds their lives are strong which made its people to be static and conservative. In Javanese society, deification and myth-making of ancestral spirits gave birth to ancestor worship, which eventually gave birth to the customary law and its supporting relations. With salvation ceremonies, the spirit of the ancestors became a protective deity for the living family. Wayang (Javanese puppet show) and Gamelan arts are used as several means of religious ritual ceremonies to bring ancestral spirits. In this ritual tradition, the ancestral spirit is considered a 'bearer' and protector of the living family.

In Wayang, ancestral spirits are personified in the form of Ponakawan. Their native religion is what anthropologists call "religion magic" and is a cultural system that is deeply rooted in Indonesian society, especially Javanese society. The existence of souls and supernatural powers is seen as God who can help or vice versa can be harmful. Therefore, W. Robertson Smith (in Ridwan, 2008) states that religious ceremonies that are usually performed by the community at that time functioned as a motivation intended not only to serve only gods or to seek inner satisfaction which was individualized, but also because they consider carrying out religious ceremonies as part of social obligations.

Since the beginning, Javanese culture that was produced during the Hindu-Buddhist period was open to accept any religion with the understanding that all religions are good, it is very natural that Javanese culture is syncretic (nature-oriented or completely loaded). Hindu-Buddhist religions in their native countries are hostile to each other, but the two can be united into a syncretistic concept of religion, namely the 'Shiva-Buddha' religion. Another feature of Javanese culture at the time was theocratic. Cult of kings as incarnations of god is one proof. In this case Onghokham (Ongkhoham n.d.) states: "In the traditional kingdom, religion is used as a form of legitimacy. In Hindu-Buddhist times the concept of god-king or god titising gods was introduced. This means that the people must submit to the position of king to achieve the salvation of the afterlife. Religion is 
integrated into the interests of the kingdom / power. Culture revolves around the king, the throne, and the palace. The king and the life of the palace is the peak of civilization at that time."

The cultivation of theocratic character and the character of the king's supremacy to his people occurred through public entertainment media, namely Wayang. In Wayang, it is exposed as a refined feudal manners and applies in the palace accompanied by melodious songs and gamelan. In the wayang story also presented the concept of Binathara with all of his powers and magical palace heirlooms. In the context of the development of palace or palace culture, this culture was developed through "palace servants" or palace employees from poets to architects. The king has interests in creating certain cultural symbols to preserve his power. Usually the culture they create is in the form of myths which then myths are collected in chronicles, saga, and so on. The goal to be achieved in creating myths is to create a culture of royal mythological symbols so that the people are loyal to the king's power.

Human trust in supranatural things mentioned by Koentjaraningrat (1994) occurs because human awareness of the existence of an invisible world of nature, which exists beyond the limits of the senses and beyond their intellect. According to human belief in many cultures in the world many referred to as the supernatural world, the unseen world is inhabited by a variety of creatures and forces that cannot be controlled by humans in ordinary ways, and which is therefore basically feared by humans. Furthermore, the belief here is the community's trust about the unseen world including the practice of shamans concerning supernatural things that occur in the community environment. This, then forms the public trust in shamans and unseen things that occur around them and the mystical phenomenon itself which then roots into today's generation.

\section{CONCLUSION}

Mystical phenomena in the form of spell activities performed by the shaman become a phenomenon which is be marketed through the texts of the song. In the commodification of media content, the message or product content is a form of commodification that collects information and data that is processed in such a way by the media to get an "exchange rate". The contents of the media, namely the mystical issues in the lyrics of Jaran Goyang became an issue that was successfully commodified in Indonesian society. This is also because most Indonesian people, especially Javanese, still believe in mystical powers. Therefore, the song that promotes shamanism is liked by many people, and inspires other recording houses to make songs with similar themes.

The commodification is a success because of the existence of an ideology of mysticism, namely people's beliefs about the unseen world, including the practice of shamans and their relations with supernatural entities. Of course in a belief system that has grown and developed for generations, it will not be easily swayed by the issue of modernization because these two things are very antithetical. In the point of view of modernization, everything is seen only through technology. However, it's different for trust since in the belief system the people would still believe in the unseen things that have been trusted by them even though to prove it is not an easy matter to do and most of the time hard to be accepted by the logical side of human mind.

\section{REFERENCES}

Aulawi, Amin. 2017. Mengenal Ajian “Kemat Jaran Goyang” Pelet Tanah Jawa Yang Bisa Bikin Cewek Klepek-klepek. May. Accessed June 1, 2018. https://www.inovasee.com/mengenalajian-kemat-jaran-goyang-25872/.

Damsar. 2011. Pengantar Sosiologi Pendidikan. Jakarta: Rajawali Pers.

Fariadi, Ruslan. 2013. "Digitalisasi Perdukunan: Mengemas Kemusyrikan Dengan Kecanggihan

Teknologi." Jurnal Tarjih dan Pengembangan Pemikiran Islam 11-19.

Geertz, Cliffort. 1963. Religion of Java. Glencoe: Free Press. 
Junus, Umar. 1986. Sosiologi Sastra: Persoalan Teori dan Metode. Kuala lumpur: Dewan Bahasa dan Pustaka Kementrian Pelajaran Malaysia.

Koentjaraningrat. 1994. Kebudayaan Jawa. Jakarta: Balai Pustaka.

Lubis, Akhyar Yusuf. 2014. Postmodernisme. Jakarta: Rajawali Press.

Mosco, Vincent. 2009. The Political Economy of Communication. Canada: SAGE Publications Ltd.

Ongkhoham. n.d. Rakyat dan Negara. Jakarta: Yayasan Obor.

Ridwan. 2008. "Mistisisme Simbolik dalam Tradisi Islam Jawa ." Jurnal Studi Islam dan Budaya 91-109.

Teeuw, A. 1984. Sastra dan Ilmu Sastra. Jakarta: Pustaka Jaya.

Wellek, Rene, and Austin Warren. 1994. Teori Kesusastraan. Translated by Melani Budianta. Jakarta: Gramedia. 